\title{
Advances in Breeding of Chrysanthemum: A Review
}

\author{
Sangeeta Kumari*, S.R. Dhiman and Y.C. Gupta \\ Department of Floriculture and Landscape Architecture, Dr. YS Parmar University of \\ Horticulture and Forestry, Nauni, Solan - 173 230, Himachal Pradesh, India \\ *Corresponding author
}

\section{A B S T R A C T}

\section{Keywords}

Conventional breeding,

Biotechnology, Agronomic traits, Transformation

Article Info

Accepted:

12 July 2019

Available Online:

10 August 2019
Chrysanthemum is among the most interesting and possibly the oldest one among the ornamental plants possessing wide genetic diversity. In recent years, researchers have used various conventional and non-conventional breeding techniques to understand the classification studies, correlation and association both at morphological and molecular level, with the wild relatives for introducing various ornamental traits from wild types to cultivated ones. Major traits which are targeted through biotechnological approaches includes development of novel flower colours, altered flower and plant morphology, insect-pest and disease resistance and enhanced post-harvest attributes. Development of varieties with novel traits provide marketing opportunities for retailers and cautious selection can increase both productivity as well as improving the quality of the products. So an attempt was made to condense the available literature that has been published on chrysanthemum breeding with more emphasis on improvement in floriculture point of view. In recent years, important strides were made in molecular breeding, particularly targeting the unusual colours through transgenics and understanding of flower genetics and flowering regulation.

\section{Introduction}

Chrysanthemum (Chrysanthemum morifolium Ramat.) is one among the most versatile and internationally recognized floriculture crop. Maximum diversity of chrysanthemum is scattered in eastern parts of the world hence also recognized as 'Queen of East', Glory of East' or 'Autumn Queen'. Fukai et al., (1995) suggested that Florists' Chrysanthemums $(2 n=54)$ originated by crossing and doubling between Chrysanthemum zawadskii var. latilobum (Maxim.) Kitamura $(2 \mathrm{n}=18)$ and Chrysanthemum indicum var. Procumbense
(Lour.) Kitamura $(2 \mathrm{n}=36)$. The cluster analysis of ISSR-PCR for 86 plants of chrysanthemum revealed that Chrysanthemum vestitum is closest to medicinal and largeflowered chrysanthemum in genetic distance and the evolution of chrysanthemum may be mainly in one way that is from wild chrysanthemum to medicinal chrysanthemum to ornamental chrysanthemum (Zhou, 2009). The genus chrysanthemum comprises of 100 to 200 species which varies in their morphological attributes like growing habit, form and colour. 


\section{Hybridization}

Availability of sufficient germplasm is prime need for further improvement in any crop. Improvement work and investigation, collection, evaluation, preservation and utilization of resources are important for the sustainable use of significant germplasm. In present, conventional breeding techniques are still being used for improving various horticulture traits in chrysanthemum.

All the cultivated chrysanthemums are allohexaploid $\quad(2 \mathrm{n}=6 \mathrm{x}=54)$ with somatic chromosomes number ranging from $2 \mathrm{n}=47$ 60 (Dowrick, 1953) with sporophytic type of self-incompatibility (Drewlow et al., 1973) involving more than one locus (Petty et al., 2003). Type of SI and its mechanism facilitates the development and production of $\mathrm{F}_{1}$ hybrid chrysanthemum cultivars seeds for use in cut flower, bedding and pot plant industries (Zagorski et al., 1983).

Interspecific hybridization clearly provides an effective means of cultivar improvement in chrysanthemum. The SI mechanism in chrysanthemum was demonstrated as change in sexual organs during pollination in cv. 'Lineker Salmon' and 'Lineker White' where pistils of the cross pollinated flowers were shriveled into the disc florets (Myung et al., 2006). However it was possible to use the pollens after long storage period over 2 months at low temperature $\left(-75^{\circ} \mathrm{C}\right.$ and $\left.-20^{\circ} \mathrm{C}\right)$. When a cross is incompatible in chrysanthemum, no pollen grain attaches to the stigma as reported by Drewlow et al., (1975) and Myung et al., (2006a). Inhibition of pollen tube growth occurred in stigmatic surface and reciprocal differences in crosses were also found (Drewlow et al., 1973).

High temperature may still be the best means of maximizing partial SI expression in chrysanthemum (Drewlow et al., 1973; Ling et al., 1966; Ronald and Ascher, 1975). High temperature treatment $\left(40^{\circ} \mathrm{C}\right.$ for $60 \mathrm{~min}$. or $50^{\circ} \mathrm{C}$ for $30 \mathrm{~min}$.) to stigma and pollen were found to be effective on overcoming of varietal crossing incompatibility in chrysanthemum as seed set was higher in treated cultivars than control (Myung et al., 2006a). Among other treatments; amino acids (alanine, arginine and glycine), IAA and nicotinic acid to stigmas can be recommended to be more effective to overcome the incompatibility in chrysanthemums and microscopic study revealed that low callosic deposit, no secretion on the stigma and collapsed papillae were observed in compatible crosses (Myung et al., 2006b).

Interspecific and intergeneric hybridization have efficiently been used with the aid of embryo rescue techniques such as embryo and ovule culture to breed novel agronomic traits and to overcome incompatibility (Watanabe, 1977) and these techniques have been applied to obtain a number of wide hybrids in Asteraceae family (Kondo et al., 1999; Abd El-Twab and Kondo, 1999; 2001, 2006; Tang et al., 2009). Ovary rescue was employed to create six interspecific hybrids from the cross between Dendranthema morifolium (Ramat.) Kitamura 'rm20-12' $(2 \mathrm{n}=54)$ and its wild diploid relative $D$. nankingense (Nakai) Tzvelev $(2 \mathrm{n}=18)$. The inheritance of branching traits identified in different cultivars of chrysanthemum revealed that two cross combinations both had cultivar 'Fukashi' as a parent exhibited branching traits as highly heritable (Yang et al., 2015). Mass selection and polycross increased the frequency of desirable individuals in the improved populations, and the variation coefficient of pyrethrin content was reduced from $29 \%$ in the base population to $18 \%$ and $16 \%$ after mass selection and polycross, respectively indicating polycross is comparatively more effective for rapid improvement of pyrethrum populations ( $\mathrm{Li}$ et 
al., 2014). The cold tolerance of five hybrids obtained was significantly superior to that of their D. morifolium parent clearly indicating interspecific hybridization as an effective means of cultivar improvement (Cheng et al., 2010).

Intergeneric hybrids between Chrysanthemum morifolium 'Nannongxiaoli' and Artemisia vulgaris 'Variegata' showed enhanced resistance against both aphids and alternaria leaf spot using ovule rescue technique as the hybrids inherited the flower quality of 'Nannongxiaoli' and favorable resistances to aphids and alternaria leaf spot from 'Variegata' Zhu et al., (2014). The results indicated intergeneric hybridization with wild species is an effective way to improve biological tolerances in chrysanthemum and can provide excellent germplasm for future chrysanthemum breeding. It is inferred by Deng et al., (2010) that higher aphid resistance in the hybrids mainly owed to the leaf micromorphology and bioactive essential oil content. In conclusion, the Chrysanthemum $\times$ Artemisia vulgaris intergeneric hybrid not only expressed greater resistance to chrysanthemum aphids than its chrysanthemum parent, but also had an improved rooting ability and a higher resistance against alternaria leaf spot infection. The results confirm once more the potential of wide sexual crossing to broaden the genetic base of chrysanthemum. GC-MS analysis has revealed that monoterpenoids and sesquiterpenoids make up of about $51 \%$ of the essential oil in the hybrid's leaves, especially 1,8-cineole, was noticeably higher in the hybrid than in the 'Zhongshanjingui' leaf owing to its resistance properties.

On the other hand, the hybrid line (female parent) could be backcrossed with 'Variegata' (male parent) to obtain the novel generation with enhanced rooting ability and disease resistance, and therein increasing plant vigour is very desirable (Deng et al., 2012).
Zhu et al., (2013) created hybrids between Chrysanthemum morifolium 'Maoyan' and Artemisia japonica Thunb. Using embryo rescue technique and cytological tests confirmed all the genuine hybrids had higher levels of chlorophyll and free proline, and lower concentrations of malondialdehyde and $\mathrm{Na}^{+}$ion than the maternal parent $(C$. morifolium), and these levels were correlated with the hybrid's enhanced salt tolerance. Sun et al., (2010) crossed Chrysanthemum grandiflorum 'Yuhuaxingchen' (excellent ornamental cultivar with low drought tolerance) with $C$. indicum having (drought tolerant) and six true hybrids with improved drought tolerance were obtained. In India, (National Botanical Research Institute) NBRI has maintained a large collection of germplasm and is the National Repository of chrysanthemum germplasm (Table 1).

\section{Mutation breeding}

Induced mutagenesis is very effective in chrysanthemum breeding method, as confirmed in the past by many researchers. In India, the success of mutation breeding in ornamentals is quite impressive.

Chrysanthemum when exposed to the effect of mutagen, most often the colour of the inflorescence changes which determines the decorative value of cultivars. The colour mutations were noted as a result of changes in the content of respective pigments (Datta and Gupta, 1981). One observes the change in the plant habit or changes in the shape and size of leaves and inflorescences or the number and shape of ligulate florets less frequently (Banerji and Datta, 1990; Zalewska, 2001, Zalewska, 2010).

Induction of mutation not only used for the improvement of flower quality parameters but also agronomic traits e.g. salt tolerance (Hossain et al., 2006) and improvement of stem quality by Lee et al., (2010) in 
chrysanthemum cv. 'Beakma' to develop stems without hollow space indicating that the treatment of gamma-ray can be an effective way introducing quality traits.

In the mutants derived from 'Lilac Wonder' there observed decrease or increase in the content of anthocyanins (Lema-Rumińska and Zalewska, 2004).

Lema-Rumińska and Zalewska, (2005) obtained, from violet pink original cultivar 'Richmond', containing anthocyanins, mutants in which there was identified the presence of carotenoids or no anthocyanins at all in ligulate florets. Many chrysanthemum cultivars have a single dominant allele responsible for the inhibition of carotenoid biosynthesis. A destruction of DNA in the area of this allele, (due to the effect of mutagen) can lead to the different carotenoids pathways in radio-mutant (Langton, 1989; Lema-Rumińska and Zalewska, 2004). The ionization irradiation can result in a partial or complete inactivation of the genes encoding the enzymes of pathway for the biosynthesis of anthocyanins. The mutations of that type which concern single genes result in the accumulation of intermediate compounds which leads to change in colour.

Mutations can also occur in the genes responsible for the production of proteins taking part in the transport of anthocyanidin pigments by membranes to vacuole where they are accumulated (Lema-Rumińska and Zalewska, 2005; Onozaki et al., 1999; Kobayashi et al., 2001). Quantitative and qualitative changes in the content of pigments in inflorescences of the cultivars obtained were a result of mutagenic gamma radiation with a dose of 15 Gy. From the parents 'Albugo', 'Alchimist', 'Satinbleu', mutants obtained in second vegetative generation, worth introducing to cultivation were 'Albugo Sunny', 'Alchimist Tubular', 'Alchimist
Golden Beet', 'Satinbleu Minty' and 'Satinbleu Honey'; respectively (Zalewska et al., 2011).

In chrysanthemum alone 49 cultivars have been commercially released in comparison to world (>281 cultivars) (Anon, 2017) (Table 2). NBRI, Lucknow has done pioneer work in the improvement of chrysanthemum. Presently, it is maintaining a living germplasm of more than 300 chrysanthemum cultivars comprising of indigenous and exotic collections and almost of all bloom types and colour which are being used as base line material for further increase of genetic variability and improvement through indiscriminate inter-varietal hybridization, induced mutagenesis and selection (Datta and Janakiram, 2015).

\section{Advances in genetic engineering}

Genetic transformation so far is the most potent tool for breeding ornamental plants. The ability to regenerate whole plants from tissue culture is a prerequisite for most transformation systems and has been achieved in $D$. grandiflora by a number of groups using various species and cultivars, basal media, different plant growth regulator (PGR) and media additive combinations and concentrations, derived organogenesis from a number of explant sources including: stems (nodes and internodes), axillary buds, leaves, shoot tips or apical meristems, protoplasts, roots, pedicels and florets (Teixeira da Silva, 2003). Because of the high level of heterozygosity and self incompatibility in chrysanthemums, seed formation is rare, which makes traditional breeding very tricky. After the first report of susceptibility of chrysanthemum to Agrobacterium (Miller, 1975), a lot of research work based on Agrobacterium-mediated transformation has been renowned. Ledger et al., (1991) first tried to generate transgenic chrysanthemum 
(Dendranthema indicum 'Korean') using Agrobacterium strain LBA4404, but reported to have very low transformation frequency $(1.7 \%)$. The transformation efficiency has been reported to be dependent not only on Agrobacterium strains but also on the nature of chrysanthemum cultivars, including their susceptibility to Agrobacterium infection and their ability to regenerate plants in vitro (Aida et al., 2004; Deroles et al., 2002; Teixeira da Silva, 2004).

Compared to rose and carnation, molecular breeding of blue colour flower in chrysanthemum is at nascent stage, although molecular genetics technology has been widely used to improve other aspects of chrysanthemum cultivar. Florigene, together with chrysanthemum breeders Fides, produced transgenic chrysanthemums expressing sense or antisense copies of the Chs gene encoding chalcone synthase (CHS) in cultivar 'Moneymaker' (pink colour), which were field tested in California and Florida. One line was named 'Floriant' (light pink to white colour), and was apparently intended as a test case for the approval procedure for genetically modified ornamentals by the Dutch government (Courtney-Gutterson et al., 1994) but did not got any commercial value because white coloured chrysanthemums were already in abundance during that time. It has long been proposed that white flowered chrysanthemums have a single dominant gene that inhibits carotenoid formation (Stewart and Derman, 1970; Jordan and ReinmannPhilipp, 1983; Hattori, 1991; Boase et al., 1997; Satoshi et al., 2012) encoding carotenoid cleavage dioxygenase 4 (CmCCD4a), which is specifically expressed in the ray petals of white-flowered chrysanthemums.

Ohmiya and co-workers (2006; 2009) reported that suppression of CmCCD4a expression by RNAi in white-flowered chrysanthemums produced yellow-flowered transformants. In other experiments (Yoshioka et al., 2010) involving crosses between whiteand yellow-flowered chrysanthemums indicated the presence of CmCCD4a led to the development of white ray petals.

Violet/blue-coloured chrysanthemums have not been generated by classical breeding practices due to the lack of a $\mathrm{F}^{\prime} 5^{\prime} \mathrm{H}$ activity. Later on $\mathrm{He}$ et al., (2013) indicated that $\mathrm{CmF3}^{\prime} \mathrm{H}$ gene in chrysanthemum is important for anthocyanin accumulation, and Senecio cruentus $\mathrm{F}^{\prime}{ }^{\prime}{ }^{\prime} \mathrm{H}$ only exhibited $\mathrm{F}^{\prime} \mathrm{H}$ activity in chrysanthemum but did not rebuild the delphinidin pathway to form blue flower chrysanthemum.

However for the first time, research teams at Florigene, Suntory, and at NARO Institute of Floricultural Science (NIFS) developed distinct genetic engineering approaches to create the long-desired violet-blue chrysanthemums by the expression of a pansy $\mathrm{F}^{\prime} 5^{\prime} \mathrm{H}$ gene under the control of a Chs promoter from rose resulted in the effective diversion of the anthocyanin pathway to delphinidin, producing transgenic daisy-type chrysanthemums. The resultant flower colour was bluish with $40 \%$ of total anthocyanidins based on delphinidin. Even higher levels of delphinidin (up to $80 \%$ ) were achieved by down- regulation of the pathway leading to cyanidin-based pigments (Brugliera et al., 2013). Likewise Noda et al., (2013) also reported that Chrysanthemum morifolium Ramat strain 94-765 and 'Taihei' could also accumulate delphinidin-based anthocyanins based on Agrobacterium mediated transformation and use of a petal-specific promoter from chrysanthemum $\mathrm{F}^{\prime} \mathrm{H}$ gene driving a Canterbury bells (Campanula medium) $\mathrm{F}^{\prime} 5^{\prime} \mathrm{H}$ gene is most suitable for production of delphinidin-based anthocyanin in the petals of chrysanthemum. 
Flower shape modification by suppression of chrysanthemum-AGAMOUS gene in cultivar 'Sei Marine' antisense orientation showed a modification of flower shape with secondary corollas as their pistils changed into several corolla-like and a pistil-like tissue. Suppression of the $C A G$ gene would modify the androecium and gynoecium to corolla-like tissues. The lack of function of androecium and gynoecium would create male and female sterile chrysanthemums and thus prevent the escape of transgenic into the natural environment, which would foster commercialization of transgenic chrysanthemums (Aida et al., 2008).

A possible strategy to speed up flowering in plants is genetic manipulation of key regulators of floral transition. Leaf explants of cultivar 'White Snowdon' were selected and cDNA (CDM111, HAM75, HAM92) was cloned to pGD121 binary vector and were transferred into Agrobacterium tumefaciens strain CBE21. They observed that under short day conditions transgenic plants (carrying compositae AP1-homologs) have started bud initiation two weeks earlier than nontransgenic control chrysanthemum plants. Later on, transgenic chrysanthemum plants colored earlier and an earlier harvesting by 5 weeks was possible compared to nontransgenic control plants (Shulga et al., 2009). New novel chrysanthemum sports and flower color differences are caused by periclinal chimerism as reported by researchers (Shibata and Kawata, 1986; Stewart and Dermen, 1970) and Aida et al., (2016) obtained chrysanthemum periclinal chimeras through regeneration from leaf explants using the fluorescent protein transgene from the marine plankton Chiridius poppei as a selection marker.

Expression of the Arabidopsis gai gene under its own promoter caused reduction in plant height in chrysanthemum by attenuation of the gibberellin response as reported by Petty et al., (2003). Two severely dwarfed lines (g16 and g1-15) and one intermediate line (g118) were produced and kept for further studies. Transgenics with altered plant architecture particularly reduced plant height will make them suitable to grow as pot plant and also avoids from indiscriminant use of chemical based growth retardants.

Recent studies showed that transgenic tobacco plants producing caffeine were resistant against tobacco cutworms (Spodoptera litura) and pathogenic microbes including Pseudomonas syringe and tobacco mosaic virus (Kim and Sano, 2008; Kim et al., 2010; Uefuji et al., 2005). These findings suggested that agriculturally important crops could be improved by endogenously producing caffeine to confer resistance against a broad range of biotic stresses including diseases and herbivorous pests. Transgenic chrysanthemum producing caffeine exhibited a high level of salicylates and a strong resistance against pathogenic fungus, Botrytis cinerea (Kim et al., 2011a). Research on resistance against beet armyworms and cotton aphids in caffeine-producing transgenic chrysanthemum was performed by Kim et al., (2011b). Chrysanthemum morifolium cv. 'Shinba' plantlets were transformed by Agrobacterium tumefaciens strain LBA4404 harboring the pBIN-NMT777, a multi-gene expression vector containing the three coffee $\mathrm{N}$ Methyltransferases genes (CaXMT1, CaMXMT1 and CaDXMT1). Transgenic chrysanthemum plants were constructed to simultaneously express three $\mathrm{N}$ methyltransferases involved in caffeine biosynthetic pathways. Resulting plants produced caffeine at approximately $3 \mathrm{mg} / \mathrm{g}^{-} 1$ fresh tissue, and were tested for herbivore repellence. When third-instars of cotton aphid (Aphis gossypii) were subjected to a choicetest, 27 gathered on wild type leaves, and 6 on transgenic leaves indicating that caffeine- 
producing chrysanthemum is resistant against herbivores, lepidopteran caterpillars and aphids, both being one of the most serious pests in agriculture.

Leaves of cut chrysanthemum show yellowing prior to onset of flower senescence and thus lowering its quality and value. Narumi et al., (2005) generated chrysanthemum plants transformed with a mutated ethylene receptor gene, derived from a chrysanthemum ethylene receptor $(D G$ ERS1) cDNA, and revealed that in vitro plantlets had reduced sensitivity to ethylene resulting in delayed leaf yellowing after exposure to exogenous ethylene. However it remained uncertain whether the suppressed sensitivity to ethylene is expressed in the leaves of mature soil grown chrysanthemum plants also. So keeping this in consideration Satoh et al., (2008) evaluated ethylene sensitivity of the transformants using soilgrown mature plants and found that in continuous light leaf senescence was delayed as compared to non-transformed leaves. Furthermore, when the detached shoots were kept in darkness without ethylene treatment, the transformants showed reduced senescence as compared with those of the nontransformed plants (Table 3).

Table.1 List of chrysanthemum cultivars released by different institutes in India

\begin{tabular}{|c|c|c|c|}
\hline Institutes & Hybridization & Selection & Mutation \\
\hline $\begin{array}{l}\text { NBRI, } \\
\text { Lucknow }\end{array}$ & $\begin{array}{l}\text { Ajay, Appu, Apsara, Apurva, Apurva Singar, Arun } \\
\text { Kumar, Arun Singar, Bindiya, Birbal Sahani, Dhawal, } \\
\text { Diana, Gauri, Gulal, Guldasta, Haldighati, Hemant } \\
\text { Singar, Himanshu, Jaya, Jayanti, Jubilee, Jwala, Jyoti, } \\
\text { Jyotsna, Kargil 99, Kaumudi, Kiran, Kirti, Kundan, } \\
\text { Lal Kila, Lalima, Lalpari, Lilith, Maghi, May-Day, } \\
\text { Mayur, Meghdoot, Mini-Queen, Mohini, Mother- } \\
\text { Teresa, NBRI Pushpangadan, NBRI Khoshoo, NBRI } \\
\text { Kaul, NBRI Himanshu, NBRI Little Orange, NBRI } \\
\text { Little Hemant, NBRI Little Kusum, NBRI Little Pink, } \\
\text { NBRI Yellow Bud Sport, Neelima, Niharika, Nirmal, } \\
\text { Pancho, Peet Singar, Phuhar, Priya, Prof. Harris, Puja, } \\
\text { Ragini, Rangoli, Sadbhavna, Shanti, Ratna, Sharda, } \\
\text { Sharad Kanti,' Sharad Kumar, Sharad Mala }\end{array}$ & & $\begin{array}{l}\text { Sharad Mukta, Sharad } \\
\text { Sandhya, Sharad Shobha, } \\
\text { Sharad Singar, Shizuka, } \\
\text { Shyamal, Suhag Singar, } \\
\text { Sujata, Suneel, Sunayana, } \\
\text { Suparna, Surekha Yellow, } \\
\text { Surya, Swarn Singar, Sweta } \\
\text { Singar, Tushar, Vandana, } \\
\text { Vasantika, Vijay, Vijay } \\
\text { Kiran, Vinaya, White } \\
\text { Charm, White Profile, Y2K, } \\
\text { Yellow Charm, Yellow } \\
\text { Prolific, NBRI Yellow Bud } \\
\text { Sport. }\end{array}$ \\
\hline $\begin{array}{l}\text { IARI, New } \\
\text { Delhi }\end{array}$ & & $\begin{array}{ll}\text { Pusa Aditya, } & \text { Pusa } \\
\text { Sona, } & \text { Pusa } \\
\text { Anmol, } & \text { Pusa } \\
\text { Chitraksha, } & \text { Pusa } \\
\text { Guldasta, } & \text { Pusa } \\
\text { Shwet } & \\
\end{array}$ & Pusa Arunodya, Pusa Kesari \\
\hline $\begin{array}{l}\text { IIHR, } \\
\text { Bengalore }\end{array}$ & $\begin{array}{l}\text { Arka Ganga, Arka Pink Star, Arka Ravi Arka Swarna, } \\
\text { Chandrakant, Chandrika, Indira, Kirti, Nilima, Pankaj, } \\
\text { Rakhee, Ravikiran, Red Gold, Yellow Star, Yellow } \\
\text { Gold, Usha Kiran }\end{array}$ & & \\
\hline $\begin{array}{l}\text { PAU, } \\
\text { Ludhiana }\end{array}$ & $\begin{array}{l}\text { Anmol, Baggi, Gul-E-Sahir, Royal Purple, Yellow } \\
\text { Delight, Autumn Joy, Garden Beauty, Winter Queen, } \\
\text { Punjab Gold, Punjab Shyamli }\end{array}$ & & \\
\hline YSP, Nauni & & Solan Shringar & \\
\hline $\begin{array}{l}\text { TNAU, } \\
\text { Coimbatore }\end{array}$ & $\mathrm{CO} 1, \mathrm{CO} 2, \mathrm{MDU}$ & & \\
\hline
\end{tabular}


Table.2 List of mutant variety released by different countries (Mutant Variety Database, 2017)

\begin{tabular}{|c|c|c|}
\hline Countries & $\begin{array}{l}\text { Varieties } \\
\text { released }\end{array}$ & \\
\hline Belgium & 7 & $\begin{array}{l}\text { Marconi, Copper Marconi, Red Marconi, Dark Red } \\
\text { Marconi, Torino, Dark Torino, Yellow Torino }\end{array}$ \\
\hline Brazil & 3 & Repin Rosa, Ingrid, Cristiane \\
\hline China & 19 & Xishihanxiao, Chuntao, Yingsidai, Mantianxin, Zixia \\
\hline India & 49 & $\begin{array}{l}\text { Agnisikha, Navneet, Subama, Sonali, Surekha Yellow, } \\
\text { Sharad Har, Navneet Yellow, Jugnu, Batik, Raktima, Kesar, } \\
\text { Lalima Tubular }\end{array}$ \\
\hline Japan & 56 & $\begin{array}{l}\text { Amazon, Araddin, Baiogiku Rainbow orange, Baiogiku } \\
\text { Rainbow Peach, Baiogiku Rainbow Pink, Baiogiku } \\
\text { Rainbow Red, Baiogiku Rainbow White, Baiogiku Rainbow } \\
\text { Yellow, Yellow Prism etc }\end{array}$ \\
\hline The Netherlands & 80 & $\begin{array}{l}\text { Amber Boston, Apricot Impala, Blue Star, Blue Winner, } \\
\text { Bronze Star, Dark Milos, Yellow Winner, Yellow Westland, } \\
\text { Yellow Clingo etc }\end{array}$ \\
\hline Germany & 34 & 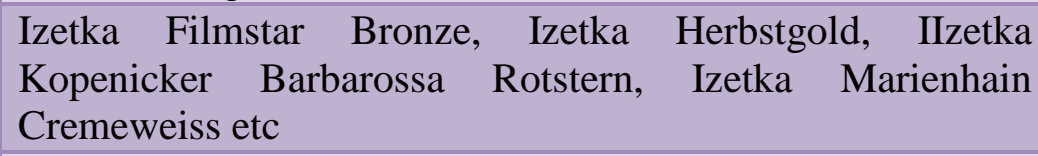 \\
\hline Poland & 6 & Lady Amber, Lady Bronze, Lady Salmon etc \\
\hline Russian & 17 & Radii, Saputnik, Selena, Sointse, Saturn etc \\
\hline Vietnam & 3 & VCM 1, VCM 2, VCM 3 \\
\hline Korean Republic & 2 & ARTI Purple, ARTI Queen \\
\hline Thailand & 1 & Golden Cremon \\
\hline
\end{tabular}

Table.3 Some of the genetic transformation studies in chrysanthemum

\begin{tabular}{|l|l|l|}
\hline Species/Cultivars & $\begin{array}{l}\text { Foreign } \\
\text { genes }\end{array}$ & References \\
\hline Dendranthema grandiflora & NPT II, GUS & $\begin{array}{l}\text { (Van Wordragen } \text { et } \\
\text { al., 1991) }\end{array}$ \\
\hline Dendranthema grandiflora cv. 'Yellow Spider' & GUS, NPT II & $\begin{array}{l}\text { (Pavingerova } \text { et al., } \\
\text { 1994) }\end{array}$ \\
\hline $\begin{array}{l}\text { Dendranthema grandiflora cv. 'Kitamura' } \\
\text { Dendranthema grandiflora cvs. 'Polaris', } \\
\text { 'Hekla', 'Iridon' }\end{array}$ & NPT II, GUS & (Seiichi et al., 1995) \\
\hline $\begin{array}{l}\text { Dendranthema grandiflora cv. 'Peach } \\
\text { Margaret' }\end{array}$ & NPT II & $\begin{array}{l}\text { (Sherman } \text { et al., } \\
\text { 1998) }\end{array}$ \\
\hline Dendranthema grandiflora & GUS & (Boase al., 1998) \\
\hline
\end{tabular}


These results demonstrated that the mutated ethylene receptor gene $m D G-E R S 1($ etrl-4) could confer reduced sensitivity to ethylene in the leaves of mature chrysanthemum plants. However, this gene may be useful to generate transgenic compositae vegetables with green leaves for a longer time and thus having a longer shelf-life. Also in some of the Asian countries, leaves of some of the chrysanthemum species are also used for edible purposes indicating its future possible use.

An Agrobacterium-mediated transformation system of pyrethrum based on leaf explants transformation was carried out by Mao et al., (2013). Further transgenic work of pyrethrum can be done for scientific studies and to improve the content of pyrethrins and other agronomical relevant traits

It is concluded presently, commercial floriculture being the most profitable business is expanding rapidly all over the world. Use of advanced science based techniques has given an impetus to the growth of this industry. Chrysanthemum is one of the most important floricultural crops in the cut flower, flowering pot plants and herbaceous perennial markets of the world. An important driving force for the floriculture industry is the development of novel features in ornamentals. Breeding for novel color, such as rare blue colour, would be valuable for the flower industry and its consumers. Conventional breeding relies primarily on selection, using natural processes of sexual and asexual reproduction. This method has long become the base of development of a lot of cultivars. While some the advanced methods like mutation breeding and genetic engineering has played key role in the development of novel and desirable traits in plants. Mutation breeding has played tremendous role in the development of large number of cultivars. Genetically modified crop plants are now grown over a very large area in several countries which is true for agriculture crops. However, it is also true to say that with a few exceptions, gene technology has not been actively pursued by the floricultural breeding companies and is also facing negative public outlook to gene technology particularly in European countries.

\section{References}

Abd El-Twab MH and Kondo K. 1999. Identification of nucleolar organizing regions and parental chromosomes in $\mathrm{F}_{1}$ hybrid of Dendranthema japonica and Tanacetum vulgare simultaneously by fluorescence in situ hybridization and fluorescence genomic in situ hybridization. Chromosome Sci 3:59-62.

Abd El-Twab MH and Kondo K. 2001. Genome territories of Dendranthema horaimontana in mitotic nuclei of $\mathrm{F}_{1}$ hybrid between $D$. horaimontana and Tanacetum parthenium. Chromosome Sci 5:63-71.

Abd El-Twab MH and Kondo K. 2006. Fluorescence in situ hybridization and genomic in situ hybridization to identify the parental genomes in the intergeneric hybrid between Chrysanthemum japonicum and Nipponanthemum nipponicum. Chromosome Bot 1: 7-11.

Aida R, Ohira K, Tanaka Y, Yoshida K, Kishimoto S, Shibata M and Ohmiya A. 2004. Efficient transgene expression in chrysanthemum (Dendranthema grandiflorum Ramat.) by using the promoter of a gene for chrysanthemum chlorophyll-a/b-binding protein. Breed Sci 54: 51-58.

Aida R, Komano M, Saito M, Nakase K and Murai K. 2008. Chrysanthemum flower shape modification by suppression of chrysanthemum-AGAMOUS gene. Plant Biotech. 25: 55-59.

Aida R, Katsumoto S and Norihiro O. 2016. Production of chrysanthemum periclinal chimeras through shoot regeneration from leaf explants. Plant Biotechnology 33, 4549.

Anonymous. 2017. Mutant variety database. https://mvd.iaea.org/ 
Banerji BK and Datta SK. 1990. Induction of somatic mutation in chrysanthemum cultivar 'Anupam'. J. Nuclear Agric. Biol. 19: 252-256.

Brugliera F, Tao GQ, Tems U, Kalc G, Mouradova E, Price K, Stevenson K, Nakamura N, Stacey L, Katsumoto Y, Tanaka Y and Mason J G. 2013. Violet/blue chrysanthemums - metabolic engineering of the anthocyanin biosynthetic pathway results in novel petal colors. Plant Cell Physiol. 54(10): 1696-1710 (2013) doi:10.1093/pcp/pct110.

Boase MR, Miller R and Deroles SC. 1997. Chrysanthemum systematics, genetics, and breeding. In: Janick J (ed) Plant Breeding Reviews, vol 14. Wiley, Hoboken, pp 321361.

Boase MR, Bradley JM and Borst NK. 1998. Genetic transformation mediated by Agrobacterium tumefaciens of florists' chrysanthemum (Dendranthema $\times$ grandiflorum) cultivar 'Peach Margaret'. In Vitro Cell Dev. Biol. Plant 34: 46-51.

Cheng X, Chen S, Chen F, Fang W, Deng Y and She L. 2010. Interspecific hybrids between Dendranthema morifolium (Ramat.) Kitamura and D. nankingense (Nakai) achieved using ovary rescue and their cold tolerance characteristics Euphytica 172:101-108

Courtney-Gutterson N, Napoli C, Lemieux C, Morgan A, Firoozabady E. and Robinson KEP. 1994. Modification of flower colour in florist's chrysanthemum: production of a white-flowering variety through molecular genetics Bio/Technol. 12: 268-271.

Datta S K and Janakiram T. 2015. Breeding and genetic diversity in Chrysanthemum morifolium Ramatin India: A review. Indian Journal of Agricultural Sciences 85(10): 1379-95.

Datta SK and Gupta MN. 1981. Cytomorphological, palynological and biochemical studies on control and gammainduced mutants of Chrysanthemum. Sabrao J. 13: 136-148.

Deng YM, Chen SM, Lu AM, Chen FD, Tang FP, Guan ZY and Teng NJ. 2010. Production and characterisation of the intergeneric hybrids between Dendranthema morifolium and Artemisia vulgaris exhibiting enhanced resistance to chrysanthemum aphid (Macrosiphoniella sanbourni). Planta 231:693-703.

Deng YM, Chen SM, Chang Q, Wang H and Chen FD. 2012. The chrysanthemum $\times$ Artemisia vulgaris intergeneric hybrid has better rooting ability and higher resistance to alternaria leaf spot than its chrysanthemum parent. Scientia Horticulturae 134: 185-190.

Deroles SC, Boase MR, Lee CE and Peters TA. 2002. Gene transfer to plants. In: Vainstein A (ed) Breeding of ornamentals: classical and molecular approaches. Kluwer, Dordrecht, pp.155-196.

Dowrick, GJ. 1953. The chromosome of chrysanthemum. II. Garden Varieties. Heredity, 7:59-72.

Drewlow LW, Ascher PD and Widmer RE. 1973. Genetic studies of self incompatibility in the garden chrysanthemum (Chrysanthemum morifolium Ramat). Theor. Appl. Genet. 43:1-5.

Drewlow LW, Ascher PD and Widmer RE. 1975. Rapid method of determining pollen incompatibility in chrysanthemum (Chrysanthemum morifolium Ramat). Euphytica 24: 29-32.

Fukai S, Jong De and Rademaker W. 1995. Efficient genetic transformation of chrysanthemum (Dendranthema grandiflora Ramat) using stem segments. Breed Sci. 45: 179-184.

Hattori K. 1991. Inheritance of carotenoid pigmentation in flower color of chrysanthemum. Jpn J Breed 41:1-9.

Hossain Z, Mandal AKA, Datta SK and Biswas AK. 2006. Development of NaCl-tolerant strain in Chrysanthemum morifolium Ramat. through in vitro mutagenesis. Plant Biology 8: 450-461.

He H, Ke H, Keting H, Qiaoyan X and Silan D. 2013. Flower colour modification of chrysanthemum by suppression of $F 3^{\prime} H$ and over-expression of the exogenous Senecio cruentus F3'5'H gene. PLoS ONE 8(11): e74395. doi:10.1371/journal.pone.0074395.

Jordan C and Reinmann-Philipp R. 1983. Investigations on type and degree of polyploidy in Chrysanthemum morifolium 
Ramat. by genetical analysis of two flower color factors. Z Pflanzenzucht 91:111-122.

Kim YS and Sano H. 2008. Pathogen resistance of transgenic tobacco plants producing caffeine. Phytochemistry 69: 882-888.

Kim YS, Choi YE, Sano H. 2010. Stimulation of defense system by caffeine production in planta. Plant Signal Behav 5: 489-493.

Kim YS, Lim S, Yoda H, Choi CS, Choi YE and Sano H. 2011a. Simultaneous activation of salicylate production and fungal resistance in transgenic chrysanthemum producing caffeine. Plant Signal Bahav 6: 409-412.

Kim YS, Lim S, Kang KK, Jung YJ, Lee YH, Choi YE and Sano H. 2011b. Resistance against beet armyworms and cotton aphids in caffeine-producing transgenic chrysanthemum Plant Biotechnology 28: 393-395.

Kobayashi S, Ishimaru M, Ding CK, Yakushiji H and Goto N. 2001. Comparison of UDPglucose: flavonoid 3-O-glucosyltransferase (UFGT) gene sequences between white grapes (Vitis vinifera) and their sports with red skin. Plant Sc. 160: 543-550.

Kondo K, Abd El-Twab MH and Tanaka R. 1999. Fluorescence in situ hybridization identifies reciprocal translocation of somatic chromosomes and origin of extra chromosomes by an artificial, intergeneric hybrid between Dendranthema japonica and Tanacetum vulgare. Chromosome Sci 3:15-19.

Langton FA. 1989. Chimerical structure and carotenoid inheritance in Chrysanthemum morifolium Ramat). Euphytica 29: 807812.

Lema-Rumińska J and Zalewska M. 2004. Studies on flower pigment of chrysanthemum mutants: Nero and Wonder Groups. Acta Sci. Pol. Hortorum Cultus 3: 125-135.

Lema-Rumińska J and Zalewska M. 2005. Changes in flower colour among Lady Group of Chrysanthemum $\times$ grandiflorum Ramat) Kitam as a result of mutation breeding. Fol. Hortic. Ann.17: 61-72.

Ledger SE, Deroles SC, Given NK. 1991. Regeneration and Agrobacterium-mediated transformation of chrysanthemum. Plant Cell Rep 10:195- 199.

Lee JH, Chung YS, Yong S, Yong K, Yoo K and
Joung YH. 2010. Induction of mutations for stem quality in chrysanthemum (Dendranthema grandiflora) by using gamma-ray irradiation. Proc. 23rd Intl. EucarpiaSymp. (Sec. Ornamentals) on "Colourful Breeding and Genetics" Part IIEds.: JM van Tuyl and DP de Vries Acta Hort. 855.

Li J, Jongsma and MA Wang. 2014. Comparative analysis of pyrethrin content improvement by mass selection, family selection and polycross in pyrethrum [Tanacetum cinerariifolium (Trevir.) Sch.Bip.] populations. Industrial Crops and Products 53: $268-273$.

Ling L, Widmer RE and Mullin R. 1966. Influence of temperature nutrition and combining ability on seed production in chrysanthemum. Proc. Amer. Soc. Hort. Sci. 88: 621-626.

Mao Jing, Caoa L Y, Konga L F, Jongsma M A and Wanga C Y. 2013. An Agrobacteriummediated transformation system of pyrethrum based on leaf explants. Scientia Horticulturae 150: 130-134

Miller HN. 1975. Leaf, stem, crown, and root galls induced in chrysanthemum by Agrobacterium tumefaciens. Phytopathology; 65: 805-811.

Myung SS, Hak KS and Ki SK. 2006a. Effect of high temperature on overcoming of varietal crossing incompatibility in chrysanthemum. Hort. Environ. Biotechnol. 47: 376-381.

Myung SS, Hak KS and Ki SK. 2006b. Effect of various treatments on the overcoming varietal crossing incompatibility in chrysanthemum. Hort. Environ. Biotechnol. 47: 288-293.

Myung SS, Myung WH, Jin HL, Seong YC, Hak KS and Ki SK. 2006. Changes in sexual organs during pollination in chrysanthemum. Hort. Environ. Biotechnol. 47: 371-375.

Narumi T, Aida R, Ohmiya A and Satoh S. 2005. Transformation of chrysanthemum with mutated ethylene receptor genes: $\mathrm{mDG}$ ERS1 transgenes conferring reduced ethylene sensitivity and characterization of transformants. Postharvest Biol. Technol. 37: 101-110.

Noda N, Aida R, Kishimoto S, Ishiguro K, 
Mizutani M F, Tanaka Y and Ohmiya A. 2013. Genetic engineering of novel bluercolored chrysanthemums produced by accumulation of delphinidin-based anthocyanins. Plant Cell Physiol. 54(10): 1684-1695.

Ohmiya A, Kishimoto S, Aida R, Yoshioka S and Sumitomo K. 2006. Carotenoid cleavage dioxygenase (CmCCD4a) contributes to white color formation in chrysanthemum petals. Plant Physiol 142:1193-1201.

Ohmiya A, Sumitomo K and Aida R. 2009. "Yellow Jimba" suppression of carotenoid cleavage dioxygenase (CmCCD4a) expression turns white chrysanthemum petals yellow. J Jpn Soc Hort Sci 78:450 455.

Onozaki T, Mato M, Shibata M and Ikeda H. 1999. Differences in flower color and pigment composition among white carnation (Dianthus caryophyllus L) cultivars. Scientia Hortic. 82: 103-111.

Pavingerova D, Dostal J, Biskova R and Benetka V. 1994. Somatic embryogenesis and Agrobacterium-mediated transformation of chrysanthemum. Plant Sci. 97: 95 - 101.

Petty LM, Harberd NP, Carre IA, Thomas B and Jackson SD. 2003. Expression of the Arabidopsis gai gene under its own promoter causes a reduction in plant height in chrysanthemum by attenuation of the gibberellin response. Plant Science 164: 175-182.

Ronald WG and Ascher PD. 1975. Effects of high temperature treatments on seed yield and self incompatibility in chrysanthemum. Euphytica 24: 317-322

Satoshi Y, Ryutaro Aida, Chihiro Y, Michio S and Akemi O. 2012. The carotenoid cleavage dioxygenase 4 (CmCCD4a) gene family encodes a key regulator of petal color mutation in chrysanthemum. Euphytica 184:377-387.

Satoh S, Watanabe M, Chisaka Keiko and Narumi T. 2008. Supressed leaf senescence in chrysanthemum transformed with a mutated ethylene receptor gene $m D G$-ERS1(etrl-4). Journal of Plant Biology 51(6): 424-427.

Seo SY, Choi DC, Kim JM, Lim HC, Kim HJ and Choi JS. 2003. Plant regeneration from leaf explants and efficient Agrobacterium- mediated transformation system of Dendranthema grandiiflorum. Acta Horticulturae 625: 403-409.

Seiichi F, DeJong J and Rademaker W. 1995. Efficient genetic transformation of Chrysanthemum (Dendranthema grandiflorum Ramat. Kitamura) using stem segments. Breed Sci 45(2):179-84

Sherman JM, Moyer JW and Daub ME. 1998. Tomato spot wilt virus resistance in chrysanthemum expressing the viral nucleocapsid gene. Plant Dis. 82: 407-414

Shibata M and Kawata J. 1986. Chimerical structure of the marble sport series in chrysanthemum. In: Kitaura K, Akihama T, Kukimura H, Nakajima K, Horie $\mathbf{M}$ and Kozaki I (eds) Development of new technology for identification and classification of tree crops and ornamentals. Fruit Tree research station, Tsukuba, pp 4752.

Shulga OA, Mitiouchkina TY, Shchennikova AV, Skryabin KG and Dolgov SV. 2009. Early flowering transgenic chrysanthemum plants. Proc. 23rd Intl. EucarpiaSymp. (Sec. Ornamentals) on "Colourful Breeding and Genetics" Eds.: J.M. van Tuyl and D.P. de Vries. Acta Hort. 836: 241-246.

Stewart RN and Derman H.1970. Somatic genetic analysis of the apical layers of chimeral sports in chrysanthemum by experimental production of adventitious shoots. Am J Bot 57:1061-1071.

Sun CQ, Chen FD, Teng NJ, Liu JL, Fang WM and Hou XL. 2010. Interspecific hybrids between Chrysanthemum grandiflorum (Ramat.) Kitamura and Chrysanthemum indicum (L.) Des Moul. and their drought tolerance evaluation Euphytica 174:51-60.

Tang FP, Chen FD, Chen SM, Teng NJ and Fang WM. 2009. Intergeneric hybridization and relationship of genera within the tribe Anthemideae Cass. (I. Dendranthema crassum (kitam.) kitam. 9 Crossostephium chinense (L.) Makino). Euphytica 169:133140.

Teixeira da Silva JA. 2003. Chrysanthemum: advances in tissue culture, cryopreservation, postharvest technology, genetics and transgenic biotechnology. Biotechnology Advance. 21: 715-766. 
Teixeira da Silva JA. 2004. Ornamental chrysanthemums: improvement by biotechnology. Plant Cell Tissue Organ Cult 79: 1-18.

Uefuji H, Tatsumi Y, Morimoto M, KaothienNakayama P, Ogita S and Sano H. 2005. Caffeine production in tobacco plants by simultaneous expression of three coffee $\mathrm{N}$ methyltransferases and its potential as a pest repellant. Plant Mol Biol 59: 221-227.

VanWordragen MF, de Jong J, Huitema HBM and Dons HJM. 1991. Genetic transformation of chrysanthemum using wild type Agrobacterium strains; strain and cultivar specificity. Plant Cell Rep. 9: 505-508.

Watanabe K. 1977. Successful ovary culture and production of $F_{1}$ hybrids and androgenic haploids in Japanese Chrysanthemum species. J Hered 68:317-320.

Yang Y, Wen C, Nan M and Zhao L. 2015. Heterosis and genetic analysis of branching in cut-flower chrysanthemums. Euphytica 205:915-925.

Yoshioka S, Sumitomo K, Fujita Y, Yamagata A, Onozaki T, Shibata $M$ and Ohmiya A. 2010. Significance of CmCCD4a orthologs in apetalous wild chrysanthemum species, responsible for white coloration of ray petals. Euphytica 171: 295-300.

Zagorski JS, Ascher PD and Widmer RE. 1983. Multigenic self incompatibility in hexaploid chrysanthemum. Euphytica 32: 1-7.

Zalewska M. 2001. In vitro formation of adventitious meristem and its significance for mutation breeding of Dendranthema grandiflora Tzvelev. Acta Horticulturae 560: 225-227.

Zalewska M. 2010. In vitro adventitious bud techniques as a tool in creation of new chrysanthemum cultivars. W: Datta, S.K., Chakrabarty, D. (eds.). Floriculture. Role of tissue culture and molecular techniques. Pointer Publishers, Jaipur, India, 189-218.

Zalewska M, Tymoszuk A and Miler N. 2011. New chrysanthemum cultivars as a result of in vitro mutagenesis with the application of different explant types. Acta Sci. Pol. Hortorum Cultus 10: 109-123.

Zhou J. 2009. Studies on the problem of origin of Chinese garden chrysanthemum. Ph.D Thesis, Beijing Forestry University, Beijing, China.

Zhu WY, Zhang F, Chen SM, Xu LL, Wang L and Wang HB. 2014. Intergeneric hybrids between Chrysanthemum morifolium 'Nannongxiaoli' and Artemisia vulgaris 'Variegata' show enhanced resistance against both aphids and alternaria leaf spot. Euphytica 197: 399-408.

Zhu W, Jiang JF, Chen S, Wang L, Xu LL, Wang HH, Li P, Guan ZY and Chen F. 2013. Intergeneric hybrid between Chrysanthemum $\mathrm{x}$ morifolium and Artemisia japonica achieved via embryo rescue shows salt tolerance. Euphytica 191: 109-119.

\section{How to cite this article:}

Sangeeta Kumari, S.R. Dhiman and Gupta, Y.C. 2019. Advances in Breeding of Chrysanthemum: A Review. Int.J.Curr.Microbiol.App.Sci. 8(08): 1631-1643. doi: https://doi.org/10.20546/ijcmas.2019.808.193 